\title{
Acute Tubular Necrosis Following Radiofrequency Ablation of a Renal Cell Carcinoma
}

\author{
Tze M. Wah · Henry C. Irving
}

Published online: 25 February 2009

(C) Springer Science+Business Media, LLC 2009

\section{Erratum to: Cardiovasc Intervent Radiol} DOI 10.1007/s00270-007-9191-6

Due to an inadvertent typesetter's error, the authors' names of this article (Tze M. Wah and Henry C. Irving) were omitted from the online and print versions of the article. They appear correctly here.

The online version of the original article can be found under doi:10.1007/s00270-007-9191-6.

T. M. Wah $(\bowtie) \cdot$ H. C. Irving

Department of Radiology, St. Jame's University Hospital,

Beckett Street, Leeds LS9 7TF, UK

e-mail: Tze.Wah@leedsth.nhs.uk 